\title{
FORANE (COMPOUND 469): 2. BIOCHEMICAL EFFECTS OF REPEATED ADMINISTRATION TO ANIMALS, RESPONSE TO BLEEDING, AND COMPATIBILITY WITH EPINEPHRINE†
}

\author{
Peter H. Byles, m.B., B.S., Allen B. Dobkin, m.d., J. Howard Ferguson, M.D. \\ AND ASHLEY A. LeVY, PH.D. $+\stackrel{+}{+}$
}

THE EXPERIMENTS REPORTED here were designed to reveal some biochemical effects which might be produced by the repeated inhalation of Forane by dogs and monkeys, and to compare its influence on the cardiac irritability of dogs with that of other halogenated anaesthetics.

\section{Methons}

\section{Biochemical Effects in Dogs}

Two groups of five mature, pedigreed, female beagles were used, having a mean body weight of $10.6 \mathrm{~kg}$. Each of the dogs in one of these groups had an open liver biopsy taken, under thiopentone anaesthesia, a month before the experiment. These received 3 hours of anaesthesia a day on five consecutive days. The other group of beagles was anaesthetized for 4 hours a day on alternate days, up to a total of 16 hours.

After food had been withheld for 12 hours, anaesthesia was induced by mask inhalation of $<4$ per cent Forane in oxygen, and the dogs were intubated. No premedication or muscle relaxant drugs were used. The animals were then connected to a non-rebreathing system, using Fink valves, and maintained under surgical anaesthesia with spontaneous respiration for the appropriate periods by the administration of between 1.0 and 1.5 per cent Forane in oxygen. Fluotec vapourisers were used which had been recalibrated by gas chromatography. Arterial and venous blood samples were drawn immediately after induction and just before termination of anaesthesia, and these were analysed by standard techniques for the variables listed in Tables I and II. No intravenous fluids were given. The blood chemistry results were studied for evidence of changes occurring during a single day's anacsthesia, those seen between the 'start' samples on the first day and the 'start' samples on the last day, and the effects of serial removal of blood.,

After the last anaesthetic, those dogs that received 3 hours of anaesthesia on five successive days were sacrificed by intravenous injection of a barbiturate, and tissue specimens of liver, kidney, pancreas, small bowel, spleen, lungs, and heart were taken for gross and microscopic examination.

${ }^{*}$ Trademark of Ohio Medical Products, Division of Air Reduction Co, Inc, Murray Hill, N.J.

†This work was supported in part by the Division of Research Facilities and Resources of NIH through grant FR 00353 and by the Ohio Medical Products Division of Air Reduction Company, Inc, Madison, Wisconsin.

$\$$ From the Department of Anesthesiology and Department of Pathology, State University of New York, Upstate Medical Center, Syracuse, New York, 13210, U.S.A. 
TABLE I

Investigation OF COMPOUND 469

BEAGLE Dog REsponses

$(3$ hours anaesthesia every day $\times 5$ )

\begin{tabular}{|c|c|c|}
\hline & $\begin{array}{c}\text { Mean of } \\
\text { start samples }\end{array}$ & $\begin{array}{c}\text { Mean of } \\
\text { end samples }\end{array}$ \\
\hline pH & $7.29 \pm 0.08^{*}$ & $7.24 \pm 0.03$ \\
\hline $\mathrm{PaCO}_{2}$ torr & $43.2 \pm 8.0$ & $53.7 \pm 9.48$ \\
\hline $\mathrm{PaO}_{2}$ torr & $353 \pm 88.6$ & $358 \pm 106$ \\
\hline Hematocrit per cent & $33.4 \pm 3.7$ & $33.2 \pm 2.1$ \\
\hline Hemoglobin $\mathrm{Gm}$ per cent & $13.6 \pm 1.7$ & $13.4 \pm 1.48$ \\
\hline Potassium $\mathrm{mEq} / \mathrm{L}$ & $3.2 \pm 0.5$ & $3.63 \pm 0.27$ \\
\hline Sodium $\mathrm{mEq} / \mathrm{L}$ & $148 \pm 12$ & $157 \pm 10$ \\
\hline Calcium mg per cent & $4.5 \pm 0.3$ & $4.5 \pm 0.2$ \\
\hline Magnesium $\mathrm{mEq} / \mathrm{L}$ & $1.4 \pm 0.1$ & $1.4 \pm 0.2$ \\
\hline Blood sugar $\mathrm{mg}$ per cent & $84 \pm 6$ & $126 \pm 14$ \\
\hline BUN mg per cent & $8.9 \pm 4$ & $11.0 \pm 3$ \\
\hline Creatinine $\mathrm{mg}$ per cent & $0.58 \pm 0.11$ & $0.43 \pm 0.07$ \\
\hline Alkaline phosphatase $\mathrm{kA}$ units & $8.7 \pm 2.9$ & $7.2 \pm 2.8$ \\
\hline Total bilirubin $\mathrm{mg} / 100 \mathrm{ml}$ & $0.31 \pm 0.22$ & $0.47 \pm 0.60$ \\
\hline SGOT units $/ \mathrm{ml}$ & $24 \pm 9$ & $16 \pm 2$ \\
\hline SGPT units $/ \mathrm{ml}$ & $35 \pm 9$ & $32 \pm 11$ \\
\hline Total protein $\mathrm{Gm}$ per cent & $5.8 \pm 0.6$ & $5.0 \pm 0.3$ \\
\hline Albumin Gm per cent & $3.3 \pm 0.3$ & $2.8 \pm 0.2$ \\
\hline Globulin Gm per cent & $2.4 \pm 0.4$ & $2.18 \pm 0.3$ \\
\hline Cortisol $\mu \mathrm{g}$ per cent & $9.8 \pm 3.8$ & $14.8 \pm 6.2$ \\
\hline
\end{tabular}

$* \pm=1$ standard deviation

Note: Summary of biochemical data from 25 experiments on 5 beagle dogs (mean weight $10.6 \mathrm{~kg}$.) that each received 3 hours of $F$ orane-oxygen anaesthesia $(>1 \%-<1.5 \%)$ on 5 consecutive days, showing mean values for all 'start' and all 'end' blood samples. Respiration was spontaneous in a non-rebreathing system.

\section{Biochemical Effects in Monkeys}

Five healthy, young rhesus monkeys weighing from 3.5 to $4 \mathrm{~kg}$ were used. Each had open liver biopsies done under thiopentone anaesthesia one month before the experiment. In the interim, they were housed in individual cages and fed a highprotein diet.

Anaesthesia was induced by placing each monkey in its cage in an airtight box, fitted with windows, containing 4 per cent Forane in oxygen. When the monkeys became unconscious, they were removed from the box, anaesthesia was deepened by mask, and an endotracheal tube was passed. This was connected to a non-rebreathing system consisting of a metered oxygen supply, a calibrated vapouriser, reservoir bag, and a Fink valve. The monkeys were warmly wrapped, kept in a high ambient temperature ( 85 to $90^{\circ} \mathrm{F}$ ), and their body temperature was monitored.

The delivered concentration of Forane was regulated to produce a surgical plane of anaesthesia with adequate spontaneous ventilation, for which 1.5 to 2.0 per cent in oxygen was required, as measured by gas chromatography. 'Start' and 'end' arterial and venous blood samples were taken and were analysed for the variables shown in Table III. The monkeys received 4 hours of anaesthesia on alternate days up to a total of 16 hours and, at the end of the last day were sacrificed and tissues were taken for examination, as with the beagle dogs. 
TABLE II

Investigation of Compound 469

BEAGLe Dog Responses

$(4$ hours anaesthesia every other day $\times 4$ )

\begin{tabular}{|c|c|c|}
\hline & $\begin{array}{c}\text { Mean of } \\
\text { start samples }\end{array}$ & $\begin{array}{c}\text { Mean of } \\
\text { end samples }\end{array}$ \\
\hline $\mathrm{pH}$ & $7.31 \pm 0.05^{*}$ & $7.28 \pm 0.04$ \\
\hline $\mathrm{PaCO}_{2}$ torr & $46.1 \pm 5.3$ & $54.1 \pm 6.1$ \\
\hline $\mathrm{PaO}_{2}$ torr & $356 \pm 141$ & $434 \pm 116$ \\
\hline Hematocrit per cent & $30.4 \pm 8.7$ & $30.5 \pm 7.1$ \\
\hline Hemoglobin $\mathrm{Gm}$ per cent & $13.5 \pm 3.7$ & $13.8 \pm 3.3$ \\
\hline Potassium mEq/L & $3.6 \pm 0.8$ & $4.0 \pm 0.7$ \\
\hline Sodium mEq/L & $160 \pm 18$ & $166 \pm 25$ \\
\hline Calcium mg per cent & $4.6 \pm 0.4$ & $4.6 \pm 0.4$ \\
\hline Magnesium mEq/L & $1.5 \pm 0.3$ & $1.6 \pm 0.1$ \\
\hline Blood sugar mg per cent & $83 \pm 18$ & $90 \pm 14$ \\
\hline BUN mg per cent & $9.3 \pm 4.4$ & $12.3 \pm 4.5$ \\
\hline Creatinine $\mathrm{mg}$ per cent & $0.79 \pm 0.15$ & $0.56 \pm 0.16$ \\
\hline Alkaline Phosphatase KA units & $8.1 \pm 2.6$ & $7.4 \pm 2.2$ \\
\hline Total bilirubin mg/100 ml & $0.18 \pm 0.23$ & $0.12 \pm 0.04$ \\
\hline SGOT units/ml & $26 \pm 5$ & $19 \pm 5$ \\
\hline SGPT units/ml & $34 \pm 10$ & $30 \pm 10$ \\
\hline Total protein Gm per cent & $5.7 \pm 0.5$ & $5.1 \pm 0.5$ \\
\hline Albumin Gm per cent & $3.0 \pm 0.3$ & $2.7 \pm 0.2$ \\
\hline Globulin Gm per cent & $2.6 \pm 0.3$ & $2.4 \pm 0.3$ \\
\hline Cortisol $\mu \mathrm{g}$ per cent & $13.3 \pm 7.7$ & $11.5 \pm 5.6$ \\
\hline
\end{tabular}

$* \pm=$ one standard deviation

Note: Summary of biochemical data from 20 experiments in 5 Beagle dogs that received 4 hours of Fornane-oxygen anaesthesia $(>1 \%-<1.5 \%)$ on 4 alternate days, showing mean values for all 'start' and all 'end' blood samples. Respiration was spontaneous in a non-rebreathing system.

\section{The Response to an Epinephrine Challenge in Dogs}

Five beagles, comparable in age and weight to the previous groups, were anaesthetized at two-week intervals, with each of five agents, in oxygen, sequentially: Forane 3 per cent, enflurane 4 per cent, halothane 1.8 percent, methoxyflurane 1.0 per cent, and fluroxene 12 per cent. Induction was by mask inhalation. Premedicant drugs, muscle relaxants, and nitrous oxide were not used. After endotracheal intubation, the dogs were ventilated by modified Harvard pumps, using a non-rebreathing circuit and a minute volume of 250 to $300 \mathrm{ml} / \mathrm{kg}$ body weight. An intravenous infusion of balanced electrolyte solution (Normosol R) was started. After 30 minutes, the arterial blood gases and $\mathrm{pH}$ were measured, and 10 micrograms per $\mathrm{kg}$ body weight of epinephrine were given intravenously over a timed period of 30 seconds through the fast-running infusion. Lead II of the electrocardiogram was continuously monitored and recorded until a normal tracing returned and persisted.

\section{Resulits}

The initial liver biopsies were all normal in the dogs and monkeys. Dogs

All animals began the tests with a mild, mixed metabolic and respiratory acidosis, a usual finding when food has been withheld and artificial ventilation has not been used during induction. Duing anaesthesia, the respiratory acidosis increased mod- 
TABLE III

INVESTIGATION OF COMPOUND 469

RhEsUS MONKEy Responses

(4 hours anaesthesia every other day $\times 4$ )

\begin{tabular}{lcc}
\hline \hline & $\begin{array}{c}\text { Mean of } \\
\text { start samples }\end{array}$ & $\begin{array}{c}\text { Mean of } \\
\text { end samples }\end{array}$ \\
\cline { 2 - 3 } $\mathrm{pH}$ & $7.39 \pm 0.03^{*}$ & $7.38 \pm 0.13$ \\
$\mathrm{PaCO}_{2}$ torr & $\mathbf{4 6} \pm \mathbf{5}$ & $45 \pm 11$ \\
$\mathrm{PaO}_{2}$ torr & $32.3 \pm 2.2$ & $438 \pm 42$ \\
Hematocrit per cent & $14.7 \pm 2.7$ & $14.0 \pm 4.0$ \\
Hemoglobin Gm per cent & $3.2 \pm 0.37$ & 3.1 \\
Potassium mEq/L & $149 \pm 6.0$ & 152 \\
Sodium mEq/L & $4.5 \pm 0.7$ & $4.6 \pm 0.2$ \\
Calcium mg per cent & $1.6 \pm 0.2$ & 1.7 \\
Magnesium mEq/L & 81 & $74 \pm 13$ \\
Blood sugar mg per cent & 20 & $23 \pm 10$ \\
BUN mg per cent & $0.7 \pm 0.3$ & $1.0 \pm 0.3$ \\
Creatinine mg per cent & $59 \pm 28$ & $41 \pm 19$ \\
Alkaline phosphatase KA units & $0.21 \pm 0.06$ & $0.21 \pm 0.12$ \\
Total bilirubin mg/100 ml & $32 \pm 12$ & $30 \pm 11$ \\
SGOT units/ml & $27 \pm 6$ & $23 \pm 6$ \\
SGPT units/ml & $7.6 \pm 0.8$ & $6.2 \pm 0.3$ \\
Total protein Gm per cent & $3.7 \pm 0.4$ & $3.3 \pm 0.6$ \\
Albumin Gm per cent & $3.7 \pm 0.9$ & $2.8 \pm 0.7$ \\
Globulin Gm per cent & $33 \pm 11$ & $36 \pm 20$ \\
Cortisol $\mu$ g per cent & & \\
\hline
\end{tabular}

$* \pm=$ one standard deviation

NoTE: Summary of biochemical data from 20 experiments in 5 Rhesus monkeys (mean weight $3.8 \mathrm{~kg}$.) that each received 4 hours of Foraneoxygen anaesthesia $(>1.5 \%-<2.0 \%)$ on 4 alternate days, showing mean values for all 'start' and all 'end' blood samples. Respiration was spontaneous in a non-rebreathing system

erately while the metabolic element remained unchanged. The serum potassium rose by about $0.4 \mathrm{mEq} / \mathrm{L}$ but without leaving the normal range. Serum sodium, which was a little high at the outset, rose a further 6 to $9 \mathrm{mEq} / \mathrm{L}$ under anaesthesia. The blood sugar showed a moderate rise but with considerable scatter. Creatinine levels fell slightly and the rise in blood urea nitrogen was within the normal range. The plasma proteins fell during anaesthesia, but the standard deviations were quite large. Physiological haemodilution, following the withdrawal of blood for analysis, was the main reason for this change (see Tables I and II).

Comparison of the 'start' samples drawn on the first and last days of the experiment showed marked falls in haemoglobin and haematocrit values (from 17.4 to $10.3 \mathrm{gm} / 100 \mathrm{ml}$ and from 43.6 per cent to 23.8 per cent respectively) due to the blood sampling. The arterial oxygen tension and the acidosis remained approximately the same. The serum potassium fell by a mean $.07 \mathrm{mEq} / \mathrm{L}$ with considerable scatter, fasting blood sugar fell from 96 to $76 \mathrm{mg}$ per cent, and plasma cortisol fell from 16.0 to $9.8 \mu \mathrm{g}$ per cent. The BuN fell from 14.3 to $7.6 \mathrm{mg} / 100 \mathrm{ml}$, as did the total plasma protein $(6.26$ to $5.26 \mathrm{gm} / 100 \mathrm{ml})$. The serum creatinine did not change. Differential blood counts showed no significant abnormalities apart from the occasional appearance of polychromasia and immature forms towards the end of the experiments, attributable to a response to blood loss. These changes indicated that the repeated 3- to 4-hour anaesthetics and blood sampling probably caused a marked physiological strain on the animals. 
Clinically, induction of anaesthesia was marked by excitement both before and while the mask was applied to the beagle dogs, but no neuromuscular disorders (twitching) and no salivation occurred. Maintenance was always smooth, and recovery of wakefulness ( $<10$ minutes) and normal ambulation ( $<15$ minutes) were always rapid. The animals looked well during recovery and took food readily within a few hours after the anaesthetic.

\section{Pathology}

Gross examination of the tissues removed did not reveal abnormalities. The microscopic examination showed that all five beagles had slight hydrops of the liver, and marked fatty infiltration of the kidneys, restricted to the ascending limbs of the loops of Henle. The other organs were all normal apart from patchy atelectasis in the lung of one dog.

\section{Monkeys}

Table III shows the mean values for all of the 'start' and all of the 'end'blood samples. The blood $\mathrm{pH}$ and gas tensions show a slight respiratory acidosis with no significant metabolic element at the start, and no change during the experiment. The electrolytes hardly changed. There was a slight over-all fall in blood sugar although it tended to rise during the individual anaesthetics. The Bun and creatinine rose overall but remained well within normal limits. The transaminases also remained normal. There was a fall in plasma protein and a slight rise in albumin/globulin ratio. Total and differential blood counts showed no significant abnormalities in counts or morphology developing during anaesthesia, although the haemoglobin and haematocrit fell from day to day. The over-all biochemical changes did not reflect as harsh a physiological effect on the monkeys as was seen in the dogs, probably because we intentionally drew much less blood from these animals.

Clinically, induction of anaesthesia was very smooth because we did not handle the animals, and emergence was equally rapid and smooth: mean wakeup time was $5.2 \pm 1.3$ minutes and ambulation occurred in $8.6 \pm 2.0$ minutes (mean and SD of 15 tests).

\section{Pathology}

Gross examination of the tissues did not reveal any pathological lesions of the vital organs. The microscopic examination of the tissue specimens showed that all the monkeys had a slight degree of fat deposition in the ascending loops of Henle of the kidney, though far less than was seen in the dogs. Slight to moderate atelectasis was present in the lungs and one monkey showed slight fatty changes in the liver. One other had focal areas of chronic pancreatitis. All other specimens were normal.

\section{Epinephrine Challenge Tests (Dogs)}

At the time of the epinephrine challenge, the dogs had a mild respiratory alkalosis with an insignificant metabolic acidosis: mean $\mathrm{PaCO}_{2}$ was 34.0 torr and $\mathrm{pH}$ was 7.43. The $\mathrm{PaO}_{2}$ values averaged 480 torr. The electrocardiographic changes seen are summarized in Table IV. No life-threatening arrhythmias occurred with any agent. Fluroxene was associated with the lowest incidence of abnormalities. Epi- 


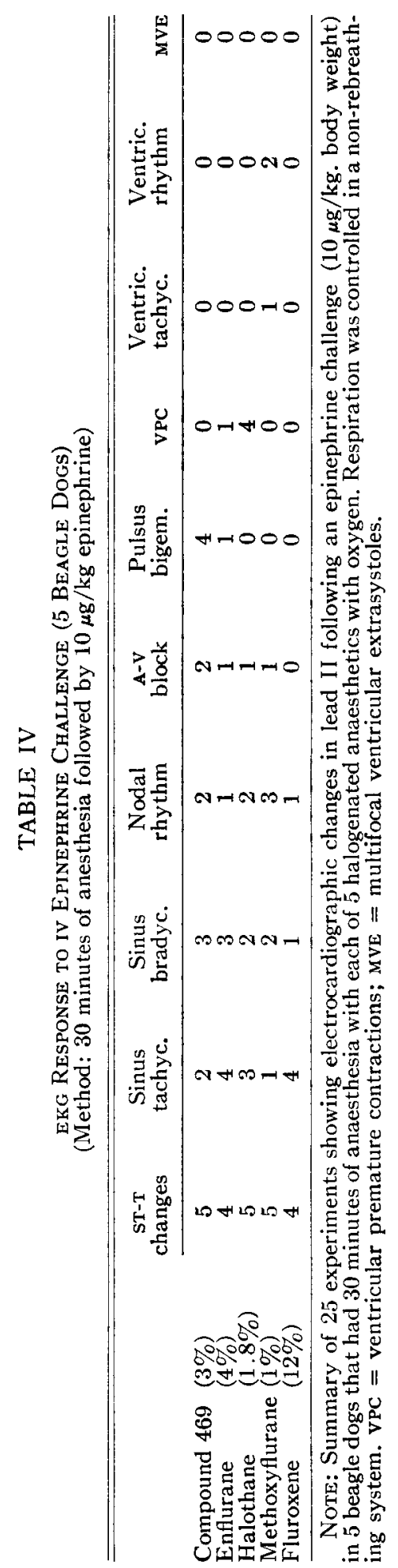


nephrine with Forane and fluroxene produced only brief supraventricular arrhythmias, while enflurane, halothane, and methoxyflurane caused ventricular arrhythmias and tachycardia, which may be considered dangerous if hypoxia or hypercarbia were present at the same time.

\section{Discussion}

The studies of Forane anaesthesia up to this point indicated that it was an effective agent in all species of animals studied. The administration of Forane in oxygen, without ancillary drugs, provided rapid induction and emergence and did not cause any deleterious biochemical effects even though dogs and monkeys were 'run down' by imposing considerable blood losses daily or every other day and by repeated long anaesthetics to the point where plasma cortisol levels were evidently depleted. ${ }^{3}$

Many epinephrine challenge studies have been reported in which a dose larger than $10 \mu \mathrm{g} / \mathrm{kg}$ of epinephrine was used, but we felt that the latter more closely approaches what would be a rather substantial amount to be absorbed within 30 seconds in normal human clinical practice.

These experiments suggest that Forane, like fluroxene, is at least as safe as and probably safer than the other agents, used in the presence of exogenous epinephrine. ${ }^{4-\tau}$ This may indicate that the rise in cortisol output during Forane anaesthesia helps to maintain the integrity and responsiveness of the myocardium to epinephrine. ${ }^{8}$

The appearance of fat deposits in the kidney troubled us because it is not generally known by clinicians whether this is a common observation in healthy mammals with or without exposure to inhalation anaesthetics. Moreover, there is little or no information which proves that the appearance of fat is permanent. We were also concerned because we had ignored the appearance of fat droplets and other abnormalities in the urine of the mongrel dogs, in the crossover study, because of the difficulty in identifying the offending anaesthetic.

After reviewing all our data on Forane, it was decided to carry out some further studies with primary emphasis on this observation, because accumulation of fat in the liver and kidney and in the urine are considered predisposing lesions of toxic tissue degeneration and cellular necrosis. ${ }^{9,10}$

The selection of methods for investigating the occurrence of parenchymatous tissue damage is not simple, particularly when the kidney and liver may be the primary target organs, because far-advanced disease or extensive structural damage usually must occur before biochemical tests show significant changes. ${ }^{11}$

The next publication will describe how we dealt with this problem.

\section{SUMMARY}

Three groups of 5 mature female beagle dogs ( 8 to $12 \mathrm{~kg}$ ) and 5 young rhesus monkeys ( 3.5 to $4.0 \mathrm{~kg}$ ) were studied after ensuring optimum nutrition and physical health.

One group of 5 beagles and the 5 monkeys had an open liver biopsy done under 
thiopentone anaesthesia one month before the tests. A second group of beagles were given serial surgical anaesthetics with Forane-oxygen in a non-rebreathing system through an endotracheal tube with attached Fink valve, allowing spontaneous breathing. Repeated arterial and venous bleedings were done for biochemical testing, to monitor blood gases and to observe the response to blood loss.

The third group of 5 beagle dogs was anaesthetized at 2-week intervals with each of 5 different agents, with oxygen, sequentially as follows: Forane 3 per cent, enflurane 4 per cent, halothane 1.8 per cent, methoxyflurane 1.0 per cent, and fluroxene 12 per cent. Induction was by mask inhalation, then endotracheal intubation and controlled ventilation with a respirator set to deliver a minute volume of 250 to $300 \mathrm{ml} / \mathrm{kg}$ body weight in a non-rebreathing circuit. After 30 minutes, arterial blood gases and $\mathrm{pH}$ were measured, then $10 \mu \mathrm{g} / \mathrm{kg}$ of epinephrine was injected intravenously in 30 seconds through a free-flowing balanced electrolyte infusion while lead In of an electrocardiogram was monitored and recorded continuously.

None of the biochemical tests indicated tissue damage. Even though the bleedings caused marked anaemia and indications of adrenocortical depletion, the stress response to Forane anaesthesia appeared to be unimpaired, i.e., the blood sugar and plasma cortisol rose during the course of each administration.

Postmortem examination of the sacrificed beagles and monkeys (that initially each had a liver biopsy, which was reported "normal section") revealed microscopic fat deposits in the loop of Henle of the kidney in all specimens, particularly evident in the beagles. The liver of most animals remained free from fat.

The 5 beagles that had 16 hours of anaesthesia had an uneventful recovery from all the tests.

During the administration of Forane and fluroxene anaesthesia, under controlled respiration, only brief supraventricular arrhythmias occurred following the intravenous injection of $10 \mu \mathrm{g} / \mathrm{kg}$ of epinephrine, while most animals developed ventricular arrhythmias or tachycardia with epinephrine during enflurane, halothane, and methoxyflurane anaesthesia. All 5 beagles survived this series of tests and appeared to be normal thereafter. We feel that these results do not indicate that epinephrine administration is completely safe with Forane and fluroxene since these animals were not hypoxic or hypercarbic at the time of the injection.

These, and preceding studies, indicated that Forane is a rapid-acting, effective anaesthetic. It appears to be safe under the stress of prolonged surgical anaesthesia and appreciable blood loss, except for the appearance of fat droplets in the loop of Henle of the kidney and in the urine. This observation was studied further and is the subject of a following publication.

\section{RÉSUMÉ}

Nous avons étudié 3 groupes de 5 adultes femelles bigles ( $8-12 \mathrm{~kg}$ ) et 5 jeunes singes rhésus $(3.5-4 \mathrm{~kg})$; les animaux étaient dans un état de nutrition et santé physique optima.

Un groupe de 5 chiens et les 5 singes avaient une biopsie ouverte du foie faite sous anesthésie au pentothal un mois avant les tests. Avec un deuzième groupe de chiens ils ont reçu des anesthésies chirurgicales au Forane-oxygène dans un système sans réinhalation par un tube endotrachéal attaché à une valve de Fink, en permettant 
aux animaux de respirer spontanément. Des saignées répétées, artérielles et veineuses, ont été faites pour des tests biochimiques, pour suivre les gaz sanguins et pour observer la réponse a l'hémorragie.

Le troisieme groupe de chiens a été endormi à un intervalle de 15 jours - avec chacun de cinq agents anesthésiques à l'oxygène, dans l'ordre suivant: forane 3 pour cent, enflurane 4 pour cent, halothane 1.8 pour cent, methoxyllurane 1.0 pour cent et fluroxene 12 pour cent. Après l'induction au masque on insérait en tube endotrachéal et on procédait à une ventilation contrôlée par un respirateur en délivrant un volume-minute de 250 a $300 \mathrm{ml} / \mathrm{kg}$ du poids corporel dans un système sans réinhalation. Trente minutes plus tard on examinait les gaz et le $\mathrm{pH}$ du sang artériel, ensuite on injectait pendant 30 secondes par la voie intraveineuse $10 \mu \mathrm{g} / \mathrm{kg}$ d'épinéphrine à travers un goutte à goutte de solution d'electrolytes balancée, tout en suivant et enregistrant contruellement l'électrocardiogramme.

Aucun des tests biochimiques n'indiquait une possibilité de dommage aux tissus. Bien que les saignées aient causé une anémie prononcée et fait apparaître des signes d'épuisement adréno-corticale, la réponse à l'agression par l'anesthésie au Forane ne paraissait pas être diminuée, c.a.d. le sucre sanguin et le cortisol du plasma montaient au cours de chaque anesthésie.

L'autopsie des chiens et singes sacrifiés (dont les biopsies hépatiques initialement faites navaient montré aucune anomalie) révélait la présence de graisse dans l'anse de Henlé dans tous les échantillons, particulièrement visibles dans ceux des beagles. Le foie de la plupart des animaux ne démontrait pas de graisse.

Les cinq chiens qui ont subi 16 heures d'anesthésie se sont rétablis complètement de tous les tests.

Pendant l'administration du Forane et fluroxene, sous respiration contrôlée, seulement des arythmies supraventriculaires de courte durée survenaient à la suite de l'injection intraveineuse de $10 \mu \mathrm{g} / \mathrm{kg}$ d'épinéphrine, tandis que la majorité des animaux endormis au halothane, méthoxyflurane ou à l'enflurane développait soit des irrégularités ventriculaires soit une tachycardie.

Tous les cinq chiens ont survécu cette série de tests et paraissaient absolument normaux par la suite.

Nous pensons que les résultats ci-dessus indiquent que l'administration d'épinéphrine pendant l'anesthésie au Forane et fluroxene n'est pas absolument sans danger, puisque les animaux n'avaient été ni sous une insuffisance d'oxygène, ni sous un excès de gaz carbonique, quand l'épinéphrine était injectée.

Les études présentées ici ainsi que les précédentes démontrent que Forane est un anesthésique effectif.

Il semble ètre sûr dans les conditions d'une anesthésie chirurgicale prolongée et d'une perte de sang appréciable.

La présence des gouttelettes de graisse dans l'anse de Henlé et dans l'urine demande des études additionelles et va être le sujet d'une publication ultérieure.

\section{REFERENCES}

1. Dobkin, A. B.; Byles, P. H.; \& Neville, J. F., Jr. Neuroendocrine and metabolic effects of general anaesthesia during spontaneous breathing, controlled breathing, mild hypoxia and mild hypercarbia. Canad. Anaesth. Soc. J., 13: 130 (1966). 
2. Dobxin, A. B.; Byles, P. H.; \& Neville, J. F., JR. Neuroendocrine and metabolic effects of general anaesthesia and graded haemorrhage. Canad. Anaesth. Soc. J., 13: 453 (1966).

3. NishioKa, K.; LevY, A. A.; \& DobxiN, A. B. Effect of halothane and methoxyflurane anaesthesia on plasma cortisol concentration in relation to major surgery. Canad. Anaesth. Soc. J., 15: 441 (1968).

4. Dobrin, A. B. \& Purkin, N. Effect of perphenazine on epinephrine-induced cardiac arrhythmias in dogs. 1. Anaesthesia with fluothane and the fluothane-ether azeotrope. Canad. Anaesth. Soc. J., 6: 243 (1959).

5. Dobkin, A. B.; Donaldson, H.; \& Punxin, N. The effect of perphenazine on epinephrineinduced cardiac arrhythmias in dogs. II. Anaesthesia with cyclopropane, chloroform, and trichlorethylene. Canad. Anaesth. Soc. J., 6: 251 (1959).

6. Israel, J. S.; Criswick, V. G.; \& Dobkin, A. B. Effect of epinephrine on cardiac rhythm during anaesthesia with methoxyflurane (Penthrane) and trifluoromethyl vinyl ether (Fluoromar). Acta Anaesth. Scandinav., 6: 7 (1962).

7. Israel, J. S.; Byles, P. H.; \& Dobrin, A. B. The cardiac effect of epinephrine during anaesthesia in hyperthryroid dogs. Canad. Anaesth. Soc. J., 9: 437 (1962).

8. RAMEY, E. R. \& GoldSTEIN, M. S. The adrenal cortex and the sympathetic nervous system. Physiol. Rev., 37: 155 (1957).

9. Sherlock, Sheila A. Diseases of the liver and biliary system. 4th ed. Oxford, Blackwell Scientific Publications ( 1968 ).

10. SMITh, Homer W. The kidney: structure and function in health and disease, 1st ed. New York: Oxford University Press (1951).

11. Schein, P. S.; Davis, R. D.; Carter, S.; Newman, J.; Schein, D. R.; \& Rall, D. P. The evaluation of anticancer drugs in dogs and monkeys for the prediction of qualitative toxicities in man. Clin. Pharmacol. \& Therap., 11: 3 (1970). 